\title{
Study of Biometric Parameters of Okra in Different Shade Net House
}

\author{
S.R. Kakade ${ }^{1 *}$, Suchita V. Gupta ${ }^{1}$, Bhagyashree N. Patil ${ }^{2}$ and Sanjivani C. Karne ${ }^{1}$ \\ ${ }^{1}$ Department of Farm Structures (ASEM), CAET, Dr. PDKV, Akola, India \\ ${ }^{2}$ Department of Agriculture Process Engineering, CAET, Dr. PDKV, Akola, India \\ *Corresponding author
}

\begin{abstract}
A B S T R A C T
Keywords

Okra, Coloured shadenet house,

Temperature, Relative humidity, Soil

temperature

Article Info

Accepted:

04 February 2018

Available Online:

10 March 2018

The experiment was conducted during winter season of 2016-2017 at the field of the Department of Farm Structures, Dr. Panjabrao Deshmukh Krishi Vidyapeeth, Akola, Maharashtra, India. The experimental site was fairly uniform and levelled. For conducting experiment the field is subdivided into four plots of $48 \mathrm{~m}^{2}(8 \mathrm{~m} \times 6 \mathrm{~m})$ and the three shadenet house has been constructed and one as open field for treatment. Three shadenet houses are of different types namely Green shadenet house, White shadenet house, Green and white strips shadenet house, Open field. The green and white strips shadenet house found more suitable to obtain significantly maximum growth of okra as compared to the white shadenet house, green shadenet house and open field. The average temperature, relative humidity, light intensity, soil temperature and carbon dioxide was observed as $35.5^{\circ} \mathrm{C}, 23.7 \%, 409.2 \mathrm{~lx}, 27.8^{\circ} \mathrm{C}$ and $655.69 \mathrm{ppm}$ respectively were found in green and white strips shadenet house. Also the growth parameters viz., plant height $(113.23 \mathrm{~cm})$, number of primary branches plant-I (12.08), canopy area $\left(2921.7 \mathrm{~cm}^{2}\right)$ and stem diameter $(1.64 \mathrm{~cm})$ were significantly increased under green and white strips shadenet house at last picking. The green and white strips shadenet house was significantly increased the growth attributes viz., plant height was $(113.23 \mathrm{~cm})$, number of primary branches plant-I was (12.08), canopy area $\left(2921.7 \mathrm{~cm}^{2}\right)$ at last picking while stem diameter $(1.64 \mathrm{~cm})$ was significantly increased under green and white strips shadenet house.
\end{abstract}

\section{Introduction}

"Okra" (Abelmoschuse sculentus L.) is an herbaceous annual plant commonly known as 'Bhindi' or 'Ladies finger'. It is grown throughout tropical and subtropical regions and also in the warmer part of the temperate region. Average area under total okra cultivation in Maharashtra during 2013-14 was 23 thousand hectare with total production of $241.50 \mathrm{MT}$ with average productivity of
$10.5 \mathrm{MT} / \mathrm{ha}$ (India Horticulture Database 2015-16).

Okra has tremendous export potential as fresh vegetable (Tiwari, 1988). The demand of fresh okra is more in external markets for green, tender and 6-9 $\mathrm{cm}$ long fruits. Among suitable varieties, Pusa Sawani, Parbhani Kranti, Varsha Uphar, Phule Utkarsha and Pusa A-4 have established in the areas raising the crop mainly for export (Jeevansab, 2000). The 
shadenet houses were used for growing of vegetable to improve quality of produce; however the area of okra crop under shadenet is very negligible. Okra crop is mostly cultivated in summer and kharif season in open field condition. Looking to the productivity of okra under open field condition, there is serious need to improve productivity of okra to meet out the growing demand of population.

Similarly different colours of shadenet having different photo chromatic effects, hence efforts has been made to know the effect of different coloured shadenet on growth, yield and quality of okra by planning. In order to study the impact of various shadenet houses under mulch on production of okra present study was undertaken (Varu, 2017; Shahak, 2008 and Ganesan, 2004).

\section{Materials and Methods}

The experiment was conducted during winter season of 2016-2017 at the field of the Department of Farm Structures, Dr. Panjabrao Deshmukh Krishi Vidyapeeth, Akola, Maharashtra, India. The experimental site was fairly uniform and levelled.

\section{Location, climate and weather condition}

Akola is situated in Western Vidarbha region of Maharashtra state and comes under subtropical zone. It was situated at an altitude of $307.415 \mathrm{~m}$ above mean sea level at the intersection of $20^{\circ} 40^{\prime}$ north latitude and $77^{\circ} 02$ ' east longitude. Average annual precipitation is $760 \mathrm{~mm}$, out of which approximately 86 per cent is received during June to September (Anonymous, 2015: Indian Horticulture Database).

The climate of the area was semi-arid, characterized by three distinct seasons; mainly summer being hot and dry from March to
May, the warm and rainy monsoon from June to October and winter with mild cold from November to February. The mean annual maximum and minimum temperature are $48.23^{\circ} \mathrm{C}$ and $22.05^{\circ} \mathrm{C}$ in summer and $32.88^{\circ} \mathrm{C}$ and $14.35^{\circ} \mathrm{C}$ in winter respectively.

For conducting experiment the field is subdivided into four plots of $48 \mathrm{~m}^{2}(8 \mathrm{~m} \times 6 \mathrm{~m})$ and the three shadenet house has been constructed and one as open field for treatment. Three shadenet houses are of different types namely

Green shadenet house (GSH)

White shadenet house (WSH)

Green and white strips shadenet house (GWSH)

Open field (OF)

\section{Observations observed}

The following observations were observed during study in the shadenet house and openfield condition.

\section{Environmental parameters}

Temperature $\left({ }^{0} \mathrm{C}\right)$

Relative humidity (\%)

Light intensity (lx $\left.10^{3}\right)$

Soil temperature $\left({ }^{0} \mathrm{C}\right)$

Carbon dioxide (ppm)

\section{Biometric characteristics}

Biometric observations like height, number leaves, fruits characteristics etc will be observed periodically during crop period. Following observations will be observed over crop period. The biometric characteristic of okra was observed at an interval of 15, 30, 45, 60, 75 and 90 days. 


\section{Growth parameter}

Plant height $(\mathrm{cm})$

No of branches plant ${ }^{-1}$

Stem diameter $(\mathrm{cm})$

Canopy area $\left(\mathrm{cm}^{2}\right)$

\section{Results and Discussion}

\section{Environmental parameter}

During the research work, it was found that the environmental parameter play an important role in growth, development and production of okra.

Temperature, relative humidity, light intensity, soil temperature and concentration of $\mathrm{CO}_{2}$ are the major factors for plant growth and it was recorded throughout the experiment from $6^{\text {th }}$ January 2017 to $10^{\text {th }}$ April 2017.

\section{Temperature}

The temperature inside the green shadenet house, white shadenet house, Green and white strips shadenet house and in open field has been recorded for 90 days of period and the average monthly readings were presented in Table 1.

\section{Effect of temperature on yield of okra in different shadenet house}

During the experiment, the temperature was observed at 8:00, 10:00, 12.00, 14:00, 16:00 and 18:00 hours is presented in Table 1. The temperature inside the shadenet house has great influenced on crop growth. It has been observed minimum temperature in GSH as compare to the GWSH and WSH during the growth stages of crop. On the other hand open field temperature was observed higher as compare to the shadenet house. The highest production of okra was found in GWSH and lowest production was found in open field.
Production of okra in GWSH was higher due to it provide favourable temperature for the germination, growth and development of crop (Bastias Richard, 2013; Bhardwaj, 2013 and Bhadur, 2009).

\section{Relative humidity}

The relative humidity inside the green shadenet house, white shadenet house, green and white strips shadenet house and in open field has been recorded for 90 days of period and the average monthly readings were presented in Table 2.

\section{Effect of relative humidity on shadenet house on yield of okra}

During the experiment, the relative humidity was observed at 8:00, 10:00, 12.00, 14:00, 16:00 and 18:00 $\mathrm{hr}$ and presented in Table 2 for different shadenet house and open field. The relative humidity inside the shadenet house has great influenced on crop growth the GSH observed minimum relative humidity as compare to the GWSH and WSH during the growth stages of crop. On the other hand relative humidity in open field was observed minimum among the shadenet house (Navale, 2003; Pandey, 2012 and Naraghi, 2010). GWSH and WSH as higher relative humidity than green shadenet house average relative humidity in GWSH and WSH approximately same. The highest production of okra was found in GWSH and lowest production was found in open field. Production of okra in GWSH was higher due to it provide favourable relative humidity for the germination, growth and development of crop.

\section{Light intensity}

The light intensity inside the green shadenet house, white shadenet house, green and white strips shadenet house and in open field has been recorded for 90 days of period and the 
average monthly readings was presented in Table 3.

\section{Effect of light intensity on shadenet house on yield of okra}

During the experiment, the light intensity was found at 8:00, 10:00, 12.00, 14:00, 16:00 and 18:00 hours. Table 3 shows average light intensity in shadenet house. From the table it was observed that light intensity was maximum in open field condition as compared to GSH, WSH, and GWSH. The light intensity found in the GSH, WSH, and GWSH is less as compared to open field. So the solar rays enters inside the shadenet house is less as compared to outside. So we get a favourable environment for the crop inside the shadenet house. The light intensity is less in morning and evening time, and it is more at afternoon. In present investigation light intensity was found in shadenet was less than open field condition.

\section{Soil temperature}

The soil temperature inside the green shadenet house, white shadenet house, Green and white strips shadenet house as well as open field has been recorded for 90 days of period and the average monthly readings were presented in Table 4.

\section{Effect of soil temperature on shadenet house on yield of okra}

During the experiment, the soil temperature was observed at 8:00, 10:00, 12.00, 14:00, 16:00 and 18:00 hours. Table 4 shows average soil temperature in shadenet house. The soil temperature inside the shadenet has great influenced on crop growth the GSH observed minimum temperature as compare to the GWSH and WSH during the growth stages of crop. On the other hand open field soil temperature was observed minimum as compare to the GWSH and WSH, GSH. The highest production of okra was found in GWSH and lowest production was found in open field. Production of okra in GWSH was higher due to it provide favourable temperature for the germination, growth and development of crop (Govindappa, 2015; Mahadeen, 2014; Dalorima, 2014; Mishra, 2009).

\section{Carbon dioxide}

The Carbon dioxide $\left(\mathrm{CO}_{2}\right)$ inside the green shadenet house, white shadenet house, Green and white strips shadenet house as well as open field has been recorded for 15 , $30,45,60,75$ and 90 days of readings were presented in Table 5.

\section{Effect of carbon dioxide $\left(\mathrm{CO}_{2}\right)$ in shadenet house on yield of okra}

The $\mathrm{CO}_{2}$ concentration in the green and white strips shadenet house observed higher $\mathrm{CO}_{2}$ concentration as compare to the white shadenet house and green shadenet house at all crop growth stages. This might be due to green and white colour decreases the crop temperature and vapour pressure deficit this leads to increase stomatal conductance and $\mathrm{CO}_{2}$ assimilate. Among the shadenet colour green shadenet colour reported lowest $\mathrm{CO}_{2}$ concentration at all the crop growth stages. The open field conditions showed lowest $\mathrm{CO}_{2}$ concentration because of less photosynthetic rate and high canopy temperature. The highest production of okra was found in GWSH and lowest production was found in open field (Lidija, 2012; Naik, 2005).

\section{Biometric observations}

The biometric observations on various growth characters viz., plant height, and number of branches, stem diameter, canopy area, days to first flower initiation and days to first harvesting were recorded. 
Table.1 Variation in average temperature of GSH, WSH, GWSH and OF with respect to time in 6 Jan to 10 April 2017

\begin{tabular}{|c|c|c|c|c|}
\hline Time & GSH & WSH & GWSH & OF \\
\hline & Temp ${ }^{\circ} \mathbf{C}$ & Temp ${ }^{\circ} \mathbf{C}$ & Temp ${ }^{\circ} \mathbf{C}$ & Temp ${ }^{\circ} \mathbf{C}$ \\
\hline $\mathbf{8}$ & 25.39 & 25.96 & 26.07 & 25.83 \\
\hline $\mathbf{1 0}$ & 32.05 & 32.96 & 33.94 & 34.69 \\
\hline $\mathbf{1 2}$ & 36.86 & 35.52 & 36.01 & 36.54 \\
\hline $\mathbf{1 4}$ & 37.31 & 36.22 & 37.01 & 38.05 \\
\hline $\mathbf{1 6}$ & 33.73 & 33.35 & 34.35 & 35.68 \\
\hline $\mathbf{1 8}$ & 28.09 & 30.43 & 30.00 & 33.25 \\
\hline
\end{tabular}

Table.2 Variation in average relative humidity GSH, WSH, WGSH and OF with respect to time in 6 Jan to 10 April 2017

\begin{tabular}{|c|c|c|c|c|}
\hline Time & GSH & WSH & WGSH & OF \\
\hline & RH \% & RH \% & RH \% & RH \% \\
\hline $\mathbf{8}$ & 31.00 & 32.54 & 33.56 & 27.45 \\
\hline $\mathbf{1 0}$ & 25.36 & 28.56 & 30.23 & 23.54 \\
\hline $\mathbf{1 2}$ & 20.80 & 21.64 & 20.96 & 19.87 \\
\hline $\mathbf{1 4}$ & 17.85 & 18.60 & 18.24 & 16.83 \\
\hline $\mathbf{1 6}$ & 17.70 & 18.55 & 17.91 & 17.09 \\
\hline $\mathbf{1 8}$ & 18.29 & 17.03 & 16.79 & 16.98 \\
\hline
\end{tabular}

Table.3 Variation in average light intensity GSH, WSH, WGSH and OF with respect to time in 6 Jan to 10 April 2017

\begin{tabular}{|c|c|c|c|c|}
\hline Time & GSH & WSH & GWSH & OF \\
\hline & $\mathbf{I x}\left(\mathbf{x} 10^{\wedge} \mathbf{3}\right)$ & $\mathbf{I x}\left(\mathbf{x} 10^{\wedge} \mathbf{3}\right)$ & $\mathbf{l} \mathbf{x}\left(\mathbf{x 1 0} 10^{\wedge} \mathbf{3}\right)$ & $\mathbf{l} \mathbf{x}\left(\mathbf{x} 10^{\wedge} \mathbf{3}\right)$ \\
\hline 8 & 295.93 & 349.35 & 345.53 & 514.03 \\
\hline 10 & 355.35 & 356.05 & 386.69 & 396.07 \\
\hline 12 & 446.55 & 447.32 & 463.67 & 686.16 \\
\hline 14 & 419.34 & 431.11 & 445.40 & 656.42 \\
\hline 16 & 433.83 & 449.07 & 458.69 & 538.53 \\
\hline 18 & 332.62 & 392.40 & 354.68 & 416.16 \\
\hline
\end{tabular}


Table.4 Variation in average soil temperature GSH, WSH, WGSH and OF with respect to time in 6 Jan to 10 April 2017

\begin{tabular}{|c|c|c|c|c|}
\hline Time & $\begin{array}{c}\text { GSH } \\
\begin{array}{c}\text { Soil } \\
\text { temp }{ }^{\circ} \mathbf{C}\end{array}\end{array}$ & $\begin{array}{c}\text { WSH } \\
\text { soil } \\
\text { temp }{ }^{\circ} \mathbf{C}\end{array}$ & $\begin{array}{c}\text { GWSH } \\
\text { somp }{ }^{\circ} \mathbf{C}\end{array}$ & $\begin{array}{c}\text { OF } \\
\text { Soil } \\
\text { temp }{ }^{\circ} \mathbf{C}\end{array}$ \\
\hline $\mathbf{8}$ & 22.39 & 23.67 & 23.73 & 22.71 \\
\hline $\mathbf{1 0}$ & 24.03 & 26.41 & 26.80 & 24.17 \\
\hline $\mathbf{1 2}$ & 25.99 & 26.58 & 26.34 & 25.86 \\
\hline $\mathbf{1 4}$ & 27.73 & 28.22 & 28.47 & 27.44 \\
\hline $\mathbf{1 6}$ & 27.63 & 28.25 & 27.88 & 27.82 \\
\hline $\mathbf{1 8}$ & 25.28 & 26.33 & 27.69 & 25.35 \\
\hline
\end{tabular}

Table.5 Variation in carbon dioxide $\left(\mathrm{CO}_{2}\right) \mathrm{GSH}$, WSH, GWSH and OF

\begin{tabular}{|c|c|c|c|c|}
\hline \multirow{2}{*}{ Treatment } & GSH & WSH & GWSH & OF \\
\hline & $\mathbf{P p m}$ & $\mathbf{P p m}$ & $\mathbf{P p m}$ & $\mathbf{P p m}$ \\
\hline $\mathbf{1 5}$ & 420.56 & 435.58 & 455.23 & 310.56 \\
\hline $\mathbf{3 0}$ & 465.89 & 495.26 & 501.23 & 325.45 \\
\hline $\mathbf{4 5}$ & $\mathbf{6 9 8 . 5 6}$ & 705.52 & 722.36 & 350.56 \\
\hline $\mathbf{6 0}$ & 700.23 & 735.52 & 780.36 & 390.25 \\
\hline $\mathbf{7 5}$ & 698.56 & 735.65 & 745.56 & 410.36 \\
\hline $\mathbf{9 0}$ & 700.56 & 705.56 & 725.85 & 401.25 \\
\hline
\end{tabular}

Table.6 Mean plant height as influenced by different shadenet house and mulch

\begin{tabular}{|l|c|c|c|c|c|c|}
\hline \multirow{2}{*}{ Treatments } & \multicolumn{7}{|c|}{ Plant height (cm) } \\
\cline { 2 - 8 } & \multicolumn{7}{|c|}{ Days } \\
\hline GSH & $\mathbf{1 5}$ & $\mathbf{3 0}$ & $\mathbf{4 5}$ & $\mathbf{6 0}$ & $\mathbf{7 5}$ & $\mathbf{9 0}$ \\
\hline WSH & 14.70 & 17.94 & 31.49 & 55.39 & 70.51 & 87.73 \\
\hline GWSH & 17.38 & 20.88 & 41.16 & 62.13 & 82.58 & 104.62 \\
\hline OF & 17.63 & 21.96 & 43.09 & 67.98 & 90.13 & 113.23 \\
\hline F TEST & 11.85 & 10.13 & 21.41 & 37.08 & 53.43 & 71.00 \\
\hline SE(m)+ & Sig. & Sig. & Sig. & Sig. & Sig. & Sig. \\
\hline CD at 1\% & 0.43 & 0.71 & 2.14 & 4.12 & 2.70 & 3.67 \\
\hline CV $(\%)$ & 1.86 & 3.05 & 9.25 & 17.80 & 11.68 & 15.87 \\
\hline
\end{tabular}


Table.7 Number of branches/plant as influenced by different shadenet house and mulch

\begin{tabular}{|l|c|c|c|c|c|c|}
\hline \multirow{2}{*}{ Treatments } & \multicolumn{6}{|c|}{ Number of branches per plant } \\
\cline { 2 - 8 } & \multicolumn{75}{|c|}{$\mathbf{3 0}$} & $\mathbf{4 5}$ & $\mathbf{6 0}$ & $\mathbf{7 5}$ & $\mathbf{9 0}$ \\
\hline GSH & 3.38 & 4.78 & 5.53 & 6.78 & 8.60 & 9.45 \\
\hline WSH & 4.68 & 5.93 & 6.93 & 8.03 & 9.98 & 11.08 \\
\hline GWSH & 5.20 & 6.80 & 7.30 & 8.85 & 10.60 & 12.08 \\
\hline OF & 2.43 & 3.50 & 4.10 & 4.70 & 6.10 & 6.80 \\
\hline F TEST & Sig. & Sig. & Sig. & Sig. & Sig. & Sig. \\
\hline SE(m)+ & 0.26 & 0.25 & 0.32 & 0.34 & 0.30 & 0.30 \\
\hline CD at 1\% & 1.14 & 1.08 & 1.40 & 1.45 & 1.31 & 1.28 \\
\hline CV $(\%)$ & 13.43 & 9.55 & 10.84 & 9.47 & 6.87 & 6.04 \\
\hline
\end{tabular}

Table.8 Stem diameter as influenced by different shadenet house and mulch

\begin{tabular}{|l|c|c|c|c|c|c|}
\hline \multirow{2}{*}{ Treatments } & \multicolumn{7}{|c|}{ Stem diameter (cm) } \\
\cline { 2 - 9 } & $\mathbf{1 5}$ & $\mathbf{3 0}$ & $\mathbf{4 5}$ & $\mathbf{6 0}$ & $\mathbf{7 5}$ & $\mathbf{9 0}$ \\
\hline GSH & 0.23 & 0.34 & 0.57 & 0.76 & 1.07 & 1.30 \\
\hline WSH & 0.32 & 0.43 & 0.72 & 0.92 & 1.22 & 1.58 \\
\hline GWSH & 0.35 & 0.44 & 0.75 & 0.94 & 1.24 & 1.64 \\
\hline OF & 0.18 & 0.24 & 0.36 & 0.56 & 0.86 & 1.05 \\
\hline F TEST & Sig. & Sig. & Sig. & Sig. & Sig. & Sig. \\
\hline SE(m)+ & 0.20 & 0.19 & 0.28 & 0.28 & 0.28 & 0.47 \\
\hline CD at 1\% & 0.88 & 0.82 & 1.19 & 1.21 & 1.21 & 2.04 \\
\hline CV $(\%)$ & 15.09 & 10.45 & 9.23 & 7.01 & 5.10 & 6.79 \\
\hline
\end{tabular}

Table.9 Canopy area as influenced by different shadenet house and mulch

\begin{tabular}{|l|c|c|c|c|c|c|}
\hline \multirow{2}{*}{ Treatments } & \multicolumn{7}{|c|}{ Canopy area $\left(\mathrm{cm}^{2}\right)$} \\
& \multicolumn{15}{|c|}{ Days } \\
\hline GSH & 246.39 & 368.97 & 544.06 & 839.37 & 1377.56 & 1807.20 \\
\hline WSH & 415.39 & 540.06 & 910.77 & 1169.80 & 2030.55 & 2814.62 \\
\hline GWSH & 487.98 & 664.86 & 932.29 & 1191.72 & 2143.04 & 2921.66 \\
\hline OF & 92.97 & 123.23 & 200.11 & 370.73 & 818.34 & 1617.58 \\
\hline F TEST & Sig & Sig & Sig & Sig & Sig & Sig \\
\hline SE(m)+ & 17.32 & 28.97 & 26.75 & 45.25 & 111.83 & 228.46 \\
\hline CD at 1\% & 74.83 & 125.15 & 115.55 & 195.51 & 483.14 & 987.06 \\
\hline CV $(\%)$ & 11.15 & 13.66 & 8.27 & 10.14 & 14.05 & 19.95 \\
\hline
\end{tabular}




\section{Growth parameters}

\section{Height of the plant $(\mathrm{cm})$}

The data pertaining to average plant height as influenced by different shadenet house and mulch is presented in Table 6. This table indicate that the mean plant height was increased progressively during growth period. The highest plant height $(113.23 \mathrm{~cm})$ was observed 90 days after sowing for the green and white strips shadenet house. Also the lowest plant height $(71.0 \mathrm{~cm})$ was observed for open field 90 days after sowing respectively.

\section{Effect of mulching in shadenet house on plant height}

The plant height of okra was influenced significantly due to different shadenet house and mulch at all crop growth stages. Plant growth and rate of branching increased mulching and early flowering in okra and also reduces the weed growth. The green and white strips shadenet house found significantly maximum plant height as compare to the green shadenet house, white shadenet house at all crop growth stages. Among the shadenet house the green shadenet house observed minimum plant height next to open field condition, it may be due to green and white strips shadenet house regulate relative humidity and canopy temperature leads to increase vegetative growth. The open field condition observed minimum plant height at all the crop growth stage, because of low relative humidity and high temperature leads to heat stress and reduces length of internode ultimately plant height was reduced. These results were in conformity with Medany et al., (2009), Yan Qinyan et al., (2011) and Rajasekar et al., (2013). From Table 6 it is seen that, at all growth stages, treatment GWSH observed significantly highest plant height and was found at par with treatment WSH. However, lowest plant height was observed in treatment. Among the shadenet house treatment GSH observed minimum plant height.

\section{Number of branches/plant}

The data pertaining to average number of branches as influenced by different shadenet house and mulch is presented in Table 7.

\section{Effect of mulching in shadenet house on number of branches per plant}

The numbers of branches per plant were influenced significantly due to different shadenet house and mulch. The green and white strips shadenet house observed significantly higher number of branches per plant as compare to the green shadenet house, white shadenet house at all growth stages. Among the shadenet house green shadenet house reported the lowest number of branches per plant at all the crop growth stages. The green and white strips shadenet house observed higher number of primary branches per plant might be due to differing optical properties of the covering material (Ghosh, S.P. 2012). Since the scattered light penetrates better into dense canopies, green and white shadenet might have favoured better scattering of light resulting into more availability of photosynthetically active radiation favouring conversion of photosynthesis into higher growth attributes. The crop grown in open field condition registered significantly the lowest number of branches per plant might be due to unfavourable climatic condition and heat stress. These finding were in the line with (Shahak et al., 2008; Medany et al., 2009 and Rajasekar et al., 2013).

From Table 7, it is seen that, at all growth stages, treatment GWSH observed significantly highest number of branches and 
was found at par with treatment WSH. However, lowest number of branches was observed in treatment OF. Among the shadenet house treatment GSH observed minimum number of branches.

\section{Stem diameter}

The data pertaining to average of stem diameter influenced by different shadenet house and mulch is presented in Table 8.

\section{Effect of mulching in shadenet house on stem diameter}

The stem diameters were influenced significantly due to different shadenet house and mulch. The green and white strips shadenet house observed significantly higher stem diameter as compare to the green shadenet house, white shadenet house at all growth stages (Basavaraja, 2003; Kittas, 2009 and Medany, 2009). Among the shadenet house green shadenet house reported the lowest stem diameter at all the crop growth stages. The crop grown under open field conditions observed significantly lowest stem diameter at all the crop growth stages because of high soil temperature reduces cell permeability for absorption of moisture and nutrients at all the crop growth stages. Similar results were also reported by Yan Qinyan et al., (2011) and Rajasekar et al., (2013). From Table 8, it is seen that, at all growth stages, treatment GWSH observed significantly highest stem diameter and was found at par with treatment WSH. However, lowest stem diameter was observed in treatment OF. Among the shadenet house treatment GSH observed minimum stem diameter.

\section{Canopy area}

The data pertaining to canopy area influenced by different shadenet house and mulch is presented in Table 9.
Effect of mulching in shadenet house on Canopy area

The canopy area was influenced significantly due to different shadenet house and mulch. The green and white strips shadenet house observed significantly higher canopy area as compare to the green shadenet house, white shadenet house at all growth stages. Among the shadenet house green shadenet house reported the lowest canopy area at all the crop growth stages. The crop grown under open field conditions observed significantly lowest canopy area at all the crop growth stages because of high soil temperature reduces cell permeability for absorption of moisture and nutrients at all the crop growth stages. Similar results were also reported by Yan Qinyan et al., (2011) and Rajasekar et al., (2013).

From Table 9 it is seen that, at all growth stages, treatment GWSH observed significantly highest canopy area and was found at par with treatment WSH. However, lowest canopy area was observed in treatment. Among the shadenet house, treatment GSH observed minimum canopy area. In green and white strips shadenet house the average temperature, relative humidity, light intensity, soil temperature and carbon dioxide were observed as $35.5^{\circ} \mathrm{C}, 23.7 \%$, $409.2 \mathrm{~lx}, 27.8^{\circ} \mathrm{C}$ and $655.69 \mathrm{ppm}$ respectively.

In open field the average temperature, relative humidity, light intensity, soil temperature and carbon dioxide were observed as $36.8^{\circ} \mathrm{C}$, $20.0 \%, 534.61 \mathrm{x}, 25.6^{\circ} \mathrm{C}$ and $364.73 \mathrm{ppm}$ respectively. The green and white strips shadenet house was significantly increased the growth attributes viz., plant height was $(113.23 \mathrm{~cm})$, number of primary branches plant-I was (12.08), canopy area $\left(2921.7 \mathrm{~cm}^{2}\right)$ at last picking while stem diameter $(1.64 \mathrm{~cm})$ was significantly increased under green and white strips shadenet house. 


\section{References}

Anonymous, 2013. Indian Horticulture Database. Published by National Horticultural Board, Ministry of Agriculture, Govt. of India, pp 152159.

Anonymous, 2014. Indian Horticulture Database 2013-2014 - NHB

Anonymous. 2011: Indian Horticulture Database. Available at www.nhb.gov.in assessed 3rd November, 2015.

Basavaraja, N., Nandi, V. R. and Praveen Jholgikar, 2003. Protected cultivation of capsicum and bhendi. Proceedings of All India on Seminar Potential and Prospects for Protective Cultivation, organized by the Institute of Engineers, Ahmednagar, December 12-13, 2003, pp. 197-199.

Bastias Richard M., Manfrini Luigi and Grappadelli Luca Corelli. 2012. Exploring the potential use of photoselective nets for fruit growth regulation in apple. Chilean J. Agril. Res. 72(2): 224-231.

Bhadur A., Singh K. P., Rai A., Verma A. and Rai, M. 2009. Physiological and yield response of okra (Abemoschuse sculentus) to irrigation scheduling and organic mulching. Indian journal of agri. sci., 79(10): 813-15.

Bhardwaj, R. 2013. Effect of mulching on crop production under rainfed condition, Agricultural Reviews. Vol. 34 Issue 3, p188.

Bushra Bibi, Muhammad Sajid and Abdur Rab. 2012. Effect of partial shade on growth and yield of tomato cultivar. J. Bio. Agri. and Health Sci. 1(1): 22-26

Costa Larissa Correa do Bomfim., Jose Eduardo Brasil Pereira Pinto., Evaristo Mauro de Castro., Eduardo Alves., Suzan Kelly VilelaBertolucci and Louise Ferreira Rosal. 2010. Effect of coloured shade netting on the vegetative development and leaf structure of
Ocimum selloi. Bragantia Campinas. 69(2): 349-359.

Dalorima, L. T., Bunu, A., Kyari, Z. and Mohammed, T. 2014. Effects of different mulching materials on the growth performance of okra in Maiduguri. International Research Journal of agricultural science and Soil Science, 4(8): 145-149.

Gadge B. Tumbare A. and Ughade S. 2016. Response of okra to different coloured shadenets and genotypes. Agronomy, Advances in Life Sciences 5(1), Print: ISSN 2278-3849, 199-203, 2016

Ganesan M., 2004. Effect of poly-greenhouse on plant microclimate and fruit yield of tomato. IE (I).J.-AG 80:12-16.

Ghosh, S.P. 2012. Carrying capacity of Indian horticulture ICAR, 68 Qutab View Apartments, Katwaria Sarai, New Delhi 110 016, India.

Jeevansab. 2000. Effect of nutrient sources on growth, yield and quality of capsicum grown under different environments. $\mathrm{M}$. Sc. (Agri.) Thesis, Univ. Agric. Sci., Dharwad, Karnataka, India.

Mahadeen, A. Y., 2014. Effect of polyethylene black plastic mulch on growth and yield of two summer vegetable crops under rain-fed conditions under semi-arid region conditions. Amer. J. Agri. Bio. Sci., 9(2), 202-207.

Megharaja, K. M. 2000. Studies on the effect of growing conditions and growth regulators on growth and productivity of hybrid capsicum cv. Indira. M. Sc. (Agri.) Thesis, Univ. Agric. Sci., Bangalore, Karnataka, India.

Mishra, J. N., Paul, J. C. and Pradhan, P. C. 2009. Response of okra to drip irrigation and mulching in coastal Orissa. Indian J. Soil Cons., 37(2): 129132.

Naik, R. K. 2005. Influence of N-aubstitution levels through organic and inorganic 
sources on growth, yield and postharvest quality of capsicum under protected condition. Ph. D. Thesis, Univ. Agric. Sci., Dharwad, Karnataka, India.

Naraghi, M. and Lotfi, M. 2010. Effect of different levels of shading on yield and fruit quality of Cucumber (Cucumis sativus). Acta Hort. Int. Soc. Horti. Sci. 871:385-388.

Navale, A. V., Nandagude, S. B., Pawar, A. G., Ghodke, H. M. and Bhosale, A. D. 2003. Comparative study of capsicum skirting and top covering effect in low cost greenhouse. In: Proc. All India Sem. Potential Prospects for Protective Cultivation Institute of Engineers, Ahmednagar, December 12-13, 2003, pp 97.

Nimje PM, Shyam M. 1993. Effect of plastic Greenhouse on plant microclimate and vegetable production. Farm. Syst. 9:1319.

Rajasekar, M., Arumugam, T., Ramesh, S. 2013. Influence of weather and growing environment on vegetable growth and yield. J. Horti. 5(10):160-167.

Shahak, Y., Elazar, G., Offir, Y and BenYakir, D. 2008. Photoselective shade netting integrated with green house technologies for improved performance of vegetable and ornamental crops. Acta Hort. 797: 7580.

Singh, A. K., Singh B. and Gupta R. 2011. Performance of sweet pepper (Capsicum annum) varieties and economics under protected and open field conditions in Uttarakhand. Indian J. Agric. Sci., 81: 973-975.

Sreedhara, D.S., Kerutagi, M.G., Basavaraja, H., Kunnal, L.B and Dodamani, M.T. 2013. Economics of capsicum production under protected condition under Northern Karnataka. Karnataka J. Agric. Sci. 26(2): 217-219.

Tiwari K. N., Mal P. K., Singh R. M. and Chattopadhyay A., 1998. Response of okra (Abelmoschuse sculantus (L.) Moench) to drip irrigation under mulch and non-mulch conditions. Agricultural Water Management. 38, 91-102.

Varu, J.D., Sarsavadiya P.N., Patil D.V. and Satasiya R.M. 2017. Winter okra response to mulch materials in net-cumpolyhouse and open field. Green Farming. 8(2): 449-453.

\section{How to cite this article:}

Kakade, S.R., Suchita V. Gupta, Bhagyashree N. Patil and Sanjivani C. Karne. 2018. Study of Biometric Parameters of Okra in Different Shade Net House. Int.J.Curr.Microbiol.App.Sci. 7(03): 43-53. doi: https://doi.org/10.20546/ijcmas.2018.703.005 